Article

\title{
Smallholder Farmers' Perceptions of Climate Change and Adaptation Practices for Maize Production in Eastern Ethiopia
}

\author{
Helen Teshome ${ }^{1, *}$, Kindie Tesfaye $^{2}\left(\mathbb{C}\right.$, Nigussie Dechassa $^{3}\left(\mathbb{D}\right.$, Tamado Tana ${ }^{4}$ and Matthew Huber ${ }^{5}(1)$ \\ 1 Africa Center of Excellence for Climate Smart Agriculture and Biodiversity Conservation, \\ Haramaya University, Dire Dawa P.O. Box 138, Ethiopia \\ 2 International Maize and Wheat Improvement Center (CIMMYT), Addis Ababa P.O. Box 5689, Ethiopia; \\ k.tesfayefantaye@cgiar.org \\ 3 College of Agriculture and Environmental Sciences, School of Plant Science, Haramaya University, \\ Dire Dawa P.O. Box 138, Ethiopia; nigussiedachassa@gmail.com \\ 4 Department of Crop Production, Faculty of Agriculture, University of Eswatini, P.O. Luyengo M205, Eswatini; \\ tamado63@yahoo.com \\ 5 Department of Earth, Atmospheric, and Planetary Sciences, Purdue University, Lafayette, IN 47907, USA; \\ huberm@purdue.edu \\ * Correspondence: helenteshome20@yahoo.com
}

\section{check for} updates

Citation: Teshome, H.; Tesfaye, K.; Dechassa, N.; Tana, T.; Huber, M. Smallholder Farmers' Perceptions of Climate Change and Adaptation Practices for Maize Production in Eastern Ethiopia. Sustainability 2021, 13, 9622. https://doi.org/10.3390/ su13179622

Academic Editors:

Irene Blanco-Gutiérrez and Rhys Manners

Received: 14 July 2021

Accepted: 20 August 2021

Published: 26 August 2021

Publisher's Note: MDPI stays neutral with regard to jurisdictional claims in published maps and institutional affiliations.

Copyright: (c) 2021 by the authors. Licensee MDPI, Basel, Switzerland. This article is an open access article distributed under the terms and conditions of the Creative Commons Attribution (CC BY) license (https:// creativecommons.org/licenses/by/ $4.0 /)$.

\begin{abstract}
Climate change and variability is affecting maize (Zea mays L.) production in eastern Ethiopia but how farmers perceive the challenge and respond to it is not well documented. A study was conducted to analyze smallholder maize farmers' perception of climate change/variability and identify their adaptation approaches and barriers for adaptation in the eastern highlands of Ethiopia. Meteorological data were assessed to provide evidence of the perceived change. A survey was conducted in six major maize-producing kebeles with a total of 364 respondents. A multi-stage sampling method was employed for selecting the sample units for the study. The data were analyzed using descriptive statistics and a multinomial logit model. The results indicated that $78 \%$ of the sampled smallholder maize farmers perceived increasing temperatures while $83 \%$ perceived decreasing amounts of rainfall. About $75 \%$ of the farmers indicated that they became aware of climate change and variability from their own experience and perceived deforestation as the main cause. The farmers perceived that drought, diseases and pests, dwindling soil fertility, and declining crop yields were the major impacts of climate change that affected maize production. The farmers' major adaptation practices include adjusting planting dates, using improved maize varieties, intercropping, recommended mineral fertilizers, supplementary irrigation, and soil and water conservation measures. Econometric analysis revealed that low educational level, shortage of land, large family sizes, age, lack of access to irrigation water, lack of access to credit, and lack of access to extension services were the most important barriers to climate change adaptation in the area. It is concluded that farmers cultivating maize in the study area have perceived climate change and use certain adaptation strategies to counter its negative impacts on maize production. This implies that policies should be geared towards strengthening farmers' efforts to adapt to climate change and alleviate the existing barriers in promoting adaptation strategies for enhancing the productivity of maize.
\end{abstract}

Keywords: adaptation practices; causes of climate change; climate variability; farmers' perception; meteorological data; Zea mays L.

\section{Introduction}

Climate change affects agriculture and food production through changing agroecological conditions [1]. Sub-Saharan Africa is the most vulnerable region to the impact of climate change and variability due to rainfall-dependent agriculture as well as weak adaptive capacity [2]. Therefore, there is a need to adopt adaptation strategies appropriate 
for the current and projected climate change [3]. Maize is a staple crop in Ethiopia and is indispensable for the livelihoods of nine million smallholder farmers in the country [4]. Despite the importance of the crop for national food security and as a source of income, the national average yield is 3.6 ton $\mathrm{ha}^{-1}$ which is low compared to the world average of 5.6 ton ha ${ }^{-1}$ [5]. The low national average yield of the crop is attributed to biotic and abiotic stresses, poor management and low use of inputs [6,7]. Among abiotic stresses, climate change in terms of increasing temperature, decreasing rainfall, and variability were found to have a great impact on maize production [8].

Farmers' perception of climate change and variability is a primary step required to take adaptation measures [9]. However, education, years spent on farming, access to extension services, and the location of farming significantly influence farmers' perception of climate change [10]. Adaptation strategies commonly used by smallholder farmers include planting different crop varieties, incorporating crop residues into the soil, soil and water conservation practices, changing dates of planting, and irrigation [11,12]. However, socio-economic and institutional factors affect climate change adaptation responses by smallholder farmers. Sisay et al. [13] reported that farmers' adaptation decisions were mainly associated with their climate change perceptions as well as socio-economic factors such as education level and farm experiences in the southern regions of Ethiopia. Adopting appropriate adaptation strategies reduce climate change impact and increase maize yield [14]. Hence, identifying the most effective adaptation strategies and technologies in a particular context is indispensable [15].

Previous studies in Ethiopia have revealed that farmers perceived climate change and adopted adaptation strategies that were influenced by socio-economic factors. The results of the studies also indicated that due to climate change-induced factors, crop productivity was affected negatively. For instance, Daba [16] reported that farmers in the western Oromia Zone in Ethiopia perceived the occurrence of climate change in terms of increase in temperatures, decrease in the amount of rainfall, and occurrence of erratic rainfall patterns as well as change in timing of rains. Tafesse et al. [17] also reported that gender, age, education, family size, access to credit, access to climate information, and extension services are the major factors influencing choices of climate change adaptation strategies in eastern Ethiopia. The finding of Abera and Tesema [11] revealed that sample respondents recognized the occurrence of climate change and its increasing adverse effects on agricultural production.

The research conducted so far in Ethiopia as well as in the study region aiming to assess farmers' perception of climate change and adaptation strategies did not adequately address the association of farmers' perception of climate change with meteorological data as well as factors affecting farmers perception of climate change and their adaptation strategies. Therefore, this paper addresses all necessary information for policymakers to design appropriate intervention strategies that fit the local condition suitable for curbing future climate change impacts on maize production and productivity. Hence, it was hypothesized that maize farmers perceive climate change and employ adaptation strategies to reduce the impact of climate change and increase yields of the crop.

Therefore, the objective of this study was to assess smallholder maize farmers' perception of climate change, their current adaptation options, and factors affecting the use of adaptation options in eastern Ethiopia.

\section{Material and Methods}

\subsection{Description of the Study Area}

The research was conducted in the eastern highlands of Ethiopia which is located between $8^{\circ} 50^{\prime}-9^{\circ} 30^{\prime} \mathrm{N}$ latitude and $40^{\circ} 38^{\prime}-42^{\circ} 20^{\prime} \mathrm{E}$ longitude (Figure 1). The altitude of the study areas ranges between 1400 and 2460 meters above sea level. The rainfall pattern of the region is bimodal. The long rainy season occurs from June to September and the short rainy season occurs from February to May [18]. In the past thirty years, more than fifty percent of the total rainfall in the districts has been received from June to September, 
with an average annual rainfall of $843 \mathrm{~mm}$. The mean annual minimum and maximum temperatures of the region are $13{ }^{\circ} \mathrm{C}$ and $26^{\circ} \mathrm{C}$, respectively (Table 1 ). The wide range of the agro-climatic zone of the region is suitable to produce different crops including cereals, pulses, oilseed, vegetables, fruits, and cash crops such as coffee (Coffee arabica L.), and khat (Catha edulis Forsk) [19].

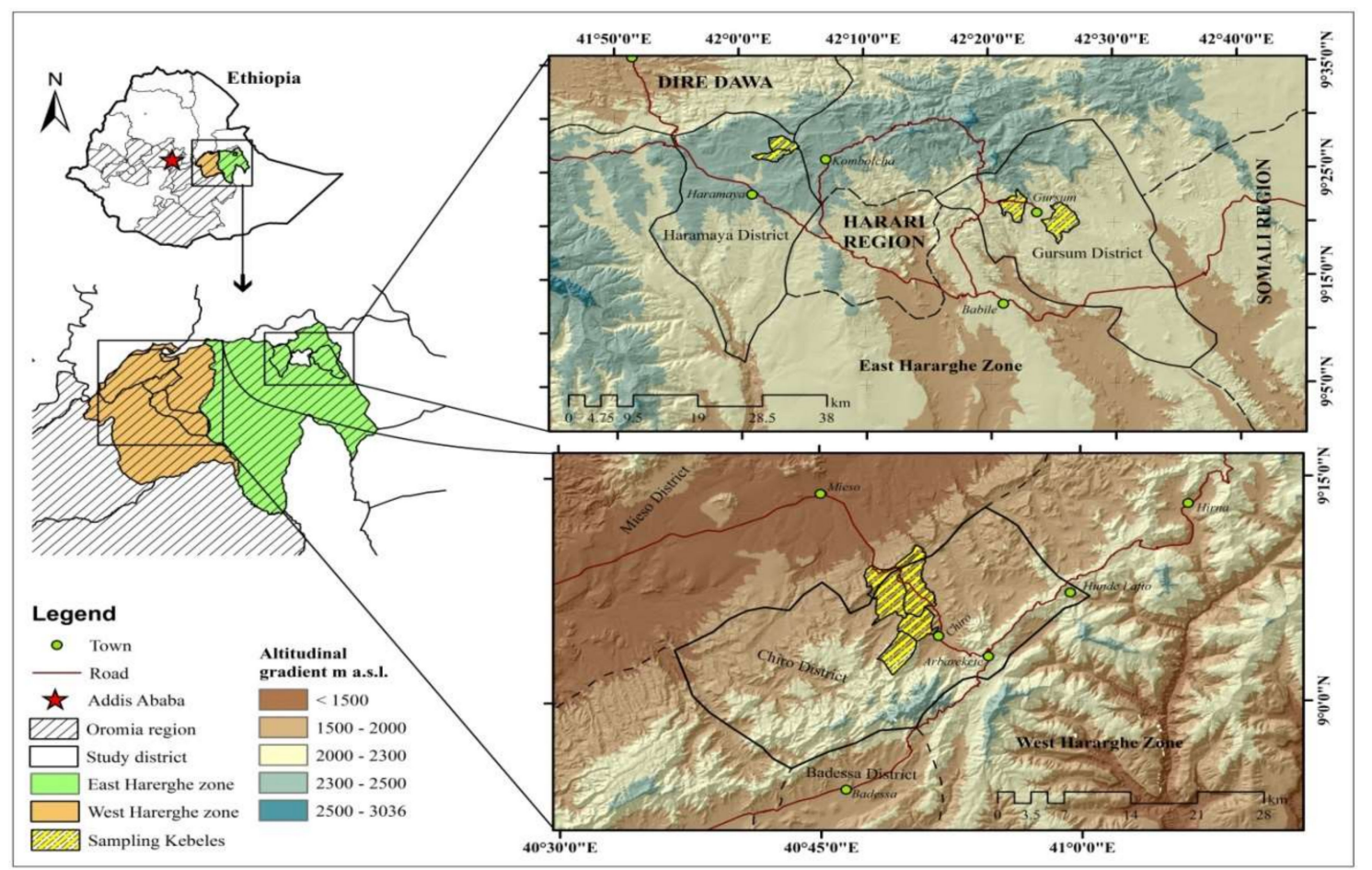

Figure 1. Map of the study area.

Table 1. The agro-ecological setting of the study districts in the eastern highlands of Ethiopia.

\begin{tabular}{cccc}
\hline & & District & \\
\hline Major Feature & Haramaya & Gursum & Chiro \\
\hline Latitude $\left(^{\circ}\right)$ & 9.4 & 9.35 & 9.07 \\
Longitude $\left({ }^{\circ}\right)$ & 42.8 & 42.4 & 40.8 \\
Altitude $(m$ a.s.l.) & $1400-2340$ & $1200-2950$ & $1501-2500$ \\
Major agro-ecological zone & Sub-humid & Semi-arid & Semi-arid \\
Climate database period & $1988-2017$ & $1988-2017$ & $1988-2017$ \\
Mean annual minimum temperature $\left({ }^{\circ} \mathrm{C}\right)$ & 9.9 & 12.7 & 13.9 \\
Mean annual maximum temperature $\left({ }^{\circ} \mathrm{C}\right)$ & 24 & 25 & 28 \\
Average Belg season rainfall $(\mathrm{mm})$ & 275 & 333 & 318 \\
Average Kiremit season rainfall $(\mathrm{mm})$ & 441 & 400 & 481 \\
Average annual rainfall $(\mathrm{mm})$ & 798 & 827 & 905 \\
Total number of households & 36,961 & 28,140 & 34,410 \\
Total population of the districts & 352,031 & 233,077 & 435,677 \\
\hline
\end{tabular}

m a.s.l = meters above sea level. Source: East and West Hararghe Zone Agriculture Offices and National Meteorological Agency (2019).

\subsection{Sampling Procedure and Sample Size}

A multi-stage sampling method was employed for selecting the sample units for the study. Three districts of the major maize crop growing areas from the East Hararghe Zone (Haramaya and Gursum) and West Hararghe Zone (Chiro) were selected purposively (Table 1). Then, two peasant associations (kebeles) were selected from each district. In Ethiopia, kebele is the smallest administrative unit. The selected kebeles were Elalemi and Muydin from Gursum district, Bachake and Tinikie from Haramaya district, and Yabdo 
Kobasa and Madicho number 3 from Chiro district, giving a total of six kebeles. The last stage involved a random selection of farmers from each kebele. A total of 364 farmers were drawn from a list comprising 4087 maize farmers as provided by the respective kebele offices which formed the sampling size. The sample size was determined as per the procedure described by [20]:

$$
n=\frac{N}{1+N\left(e^{2}\right)}
$$

where, $n=$ sample size; $N=$ population size; and $e=$ level of precision at 0.05 . Then, the sample size of each kebele was determined by dividing the total number of households producing maize in the kebele by the total number of households producing maize in the six kebeles and multiplying it by the sample size of the study area (Table 2).

Table 2. Distribution of sample households by peasant association.

\begin{tabular}{cccc}
\hline District & Kebele & Household Size & Sample Size \\
\hline Haramaya & Bachake & 436 & 39 \\
& Tinike & 583 & 52 \\
\hline \multirow{2}{*}{ Gursum } & Elalem & 600 & 53 \\
& Muydin & 781 & 70 \\
Chiro & Yabdo Kobasa & 692 & 62 \\
& Madicho No. 3 & 995 & 88 \\
\hline Total & & 4087 & 364 \\
\hline
\end{tabular}

Source: East and West Hararghe Zone Agriculture Offices (2019).

\subsection{Data Collection Methods}

A questionnaire was designed in line with the planned objectives. A well-validated open and close-ended questionnaire was translated into the local Oromo language for easy understanding during primary data collection. The questionnaire was pre-tested in each study district before undertaking the survey. The questionnaire included diverse issues that could provide an understanding of the demographic and socioeconomic attributes of farm households, including the following topics: (1) farmers perceptions of climate change, (2) perception on causes of climate change, (3) impact on maize production, (4) adaptation options practiced to reduce the impact, (5) factors influencing their adaptation decisions as well as their needs from governmental and non-governmental organizations to resolve the barriers and hence to increase their adaptive capacity. In addition to administering the household-level open-ended survey questionnaire, Key Informant Interviews (KIIs) and Focus Group Discussions (FGDs) were used for data collection.

The questionnaire was administered with the help of development agents from the local agriculture offices that had been trained before the data collection. Information was provided for the head of the household on the overall objectives of the research and a common understanding was reached with him/her for conducting a face-to-face interview. Collection of the household data was undertaken from September to December 2019. A total of six groups, two groups per district of farmers ranging in number from eight to ten men and women were selected randomly for the focus group discussions. Several key informant interviews were made with key district personnel as well as heads of kebeles to cross-check the information obtained from the interview of the household heads. Secondary data were gleaned from the literature, documentation centers, the office of statistics in the respective kebeles and districts, and the national meteorological agency to consolidate the information obtained during primary data collection and support the results of the study.

\subsection{Analytical Methods}

\subsubsection{Descriptive Analysis}

Descriptive statistics such as mean, frequency, percentage, and standard deviations were used to visualize and analyze the data. Before analyzing the meteorological data, 
quality control methods were employed. To fill the missing values following the Markov chain model, INSTAT software version 3.37 was used [21]. The Tukey fence was used to screen outliers greater or less than a threshold value and set to the limit corresponding to $\pm 1.5 \times \mathrm{IQR}$ [22]. Four methods were applied to test the data for homogeneity, which are Alexandersson's Standard Normal Homogeneity Test (SNHT) [23], the Buishand range test (BRT) [24], Pettitt test [25], and Von Neumann ratio (VNR) tests [26]. These tests were performed under two hypotheses: $\mathrm{H} 0$ (null hypothesis), data are homogeneous; and $\mathrm{Ha}$ (alternative hypothesis), there is a date at which there is a change in the data.

The time-series data were tested for randomness and independence using the autocorrelation function $\left(r_{1}\right)$ as described in [27],

$$
r_{1}=\frac{\sum_{i=1}^{n-1}\left(x_{i}-\bar{x}\right)\left(x_{i+1}-\bar{x}\right)}{\sum_{i=1}^{n}\left(x_{i}-\bar{x}\right)^{2}}
$$

where $x_{i}$ is an observation, $x_{i+1}$ is the following observation, $\bar{x}$ is the mean of the time series, and $n$ is the number of data. The autocorrelation coefficient value of $r_{1}$ was tested against the null hypothesis at a $95 \%$ confidence interval, using a two-tailed test:

$$
r_{1}=\frac{-1 \pm 1.96 \sqrt{(n-2)}}{n-1}
$$

Whenever significant correlation appeared in the data series, a pre-whitened approach was used following the procedure described by [28], which was obtained as: $\left(x_{2}-r_{1} x_{1}, x_{3}-r_{1} x_{2}, \ldots, x_{n}-r_{1} x_{n-1}\right)$ where $x_{1}, x_{2}, x_{3} \ldots x_{n}$ are data points of the series. The outlier detection, homogenization, and autocorrelation were achieved using XLSTAT statistical software. To assess the trend in rainfall data, the Mann-Kendall trend test was applied $[29,30]$. The non-parametric method described by [31] was also used to estimate the magnitude of trends in the data time series.

\subsubsection{Econometric Analysis}

Pearson's correlations were calculated for the relationship among independent (explanatory) variables. The multinomial logit (MNL) model was applied to explore factors affecting farmers' perception of temperature and rainfall and the use of adaptation strategies by smallholder maize farmers to reduce the impact of climate change in the study area. MNL is widely employed in climate change adaptation studies [2,32]. The question is how changes in the elements of $X$ effect, keeping other factors constant, and the response probabilities, $P(Y=j \mid x), j=0.1,2 \ldots J . P(Y=j \mid x)$ are known after determining the probabilities for $j=2 \ldots J$. Since the probabilities must sum to unity, Let $\times$ be a $1 \times K$ vector with the first element unity. Thus, the probability that a household $i$ with a characteristic $X$ chooses an adaptation option $j$ is specified following [33]:

$$
P\left(Y_{i}=j \mid x\right)=\frac{\exp \left(x \beta_{j}\right)}{\left[1+\sum_{j=1} \exp (x \beta j)\right]}
$$

where $P$ stands for probability, $j$ stands for adaptation options, $x$ for explanatory variables and $\beta_{j}=k \times 1$ is coefficients, $j=1,2, \ldots, \mathrm{M}$. The dependent variables included in the model in this study were adaptation strategies used by maize farmers in the study area which was obtained from the survey data collected. The variables included planting dates, changing maize varieties, intercropping, recommended mineral fertilizer application, supplemental irrigation, and soil and water conservations practices. The independent (explanatory) variables were obtained from the survey data (Table 3 ).

However, the MNL model suffers from problems of independence and works under the assumption of Independent Irrelevant Alternatives (IIA), which states that the ratio of the probabilities of choosing any two alternatives is independent of the attributes of any 
other alternatives in the choice set. Hausman test [34] was used to test the validity of the IIA assumption. Data were analyzed using STATA software [35].

Table 3. Description of explanatory variables used in the model.

\begin{tabular}{|c|c|}
\hline Variable & Measurement \\
\hline Age & Continuous (years) \\
\hline Education level & Dummy $1=$ Illiterate, $0=$ otherwise \\
\hline Land size & Continuous (hectare) \\
\hline Family size & Continuous (number) \\
\hline Access to irrigation water & Dummy $1=$ If there is access, $0=$ otherwise \\
\hline Access to extension services & Dummy $1=$ If there is access, $0=$ otherwise \\
\hline Haramaya & Dummy 1 if the district is Haramaya, $0=$ otherwise \\
\hline Gursum & Dummy 1 if the district is Gursum, $0=$ otherwise \\
\hline Chiro & Dummy 1 if the district is Chiro, $0=$ otherwise \\
\hline
\end{tabular}

\section{Results and Discussion}

\subsection{Demographic and Socioeconomic Characteristics}

The results of farmers' socio-economic and demographic characteristics show that from the total 364 farm households interviewed in the districts, $94 \%$ were male-headed whereas $6 \%$ were female-headed (Figure 2). This difference may be attributed to cultural norms which give family leading roles to men and child care and house chores to women. Consistent with this suggestion, [36] reported that agricultural activities are physically demanding so that most communities consider these as inappropriate for women. The data also indicated that about $94 \%$ of the farm households are married.

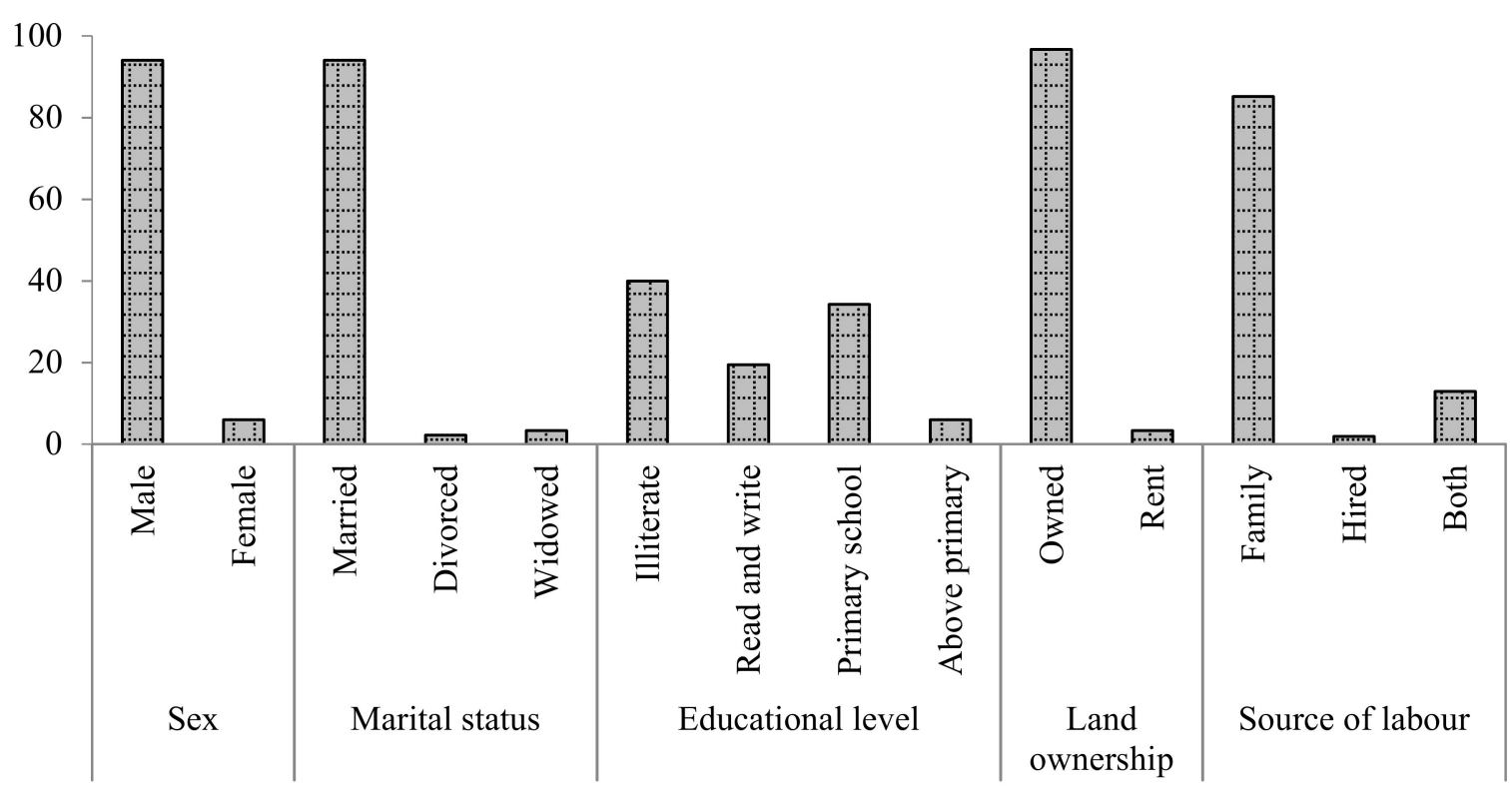

Figure 2. Characteristics of the farm households in the study districts of the eastern highlands of Ethiopia $(N=364)$.

Concerning educational level, the heads of $59 \%$ of the households were able to read and write or had attended at least primary education, and a few of them had attended secondary education and above. The average education levels of the farm households in this study were found to be somewhat higher than that of the national average of 2017 which is 5\% [37]. Perhaps it may be because the interviewed household heads in the study area live near towns and may have access to educational institutions to upgrade their level of education. Additionally, smallholder maize farmers may have a better understanding of climate change and could implement adaptation strategies. Consistent with this suggestion, 
Amare and Simane [38] stated that education helps farmers to anticipate the consequences of climate change and understand the potential benefits of adopting different strategies to tackle the challenges. Almost all of the households (97\%) owned land for cultivation whereas the remaining households rented land from other farmers to produce maize. The majority of the farm households used family labor and a few used both family and hired labor particularly during peak seasons of work (planting, management, and harvesting). It was found that only a few households whose family members were below the working-age used hired labor.

On average, the age of the household heads in the study area was in the range of 29 to 72 years. The interviews were conducted with $59 \%$ of the farm households above the age of 40 years (Table 4 ). Regarding farming experience in the districts, farm households had more than 20 years of experience. The farming experience of the household was mostly related to age. This implies that the older the household head, the more reliable the information he would provide on climate change and variability. Consistent with this suggestion, Montle and Teweldemedhin [39] stated that the older the farmer, the more experienced and better exposed he or she is to present and past climatic conditions. Additionally, Tadesse et al. [40] reported a positive relationship between experience in agriculture and the adoption of improved agricultural technologies.

Table 4. Characteristics (mean and standard deviation) of the farm households in the eastern highlands of Ethiopia $(N=364)$.

\begin{tabular}{ccccc}
\hline Variable & Haramaya & Gursum & Chiro & Average \\
\hline Age of farm household (years) & $41.9 \pm 11.2$ & $39.5 \pm 10.6$ & $44.3 \pm 11.0$ & $42.4 \pm 11.1$ \\
Farming experience (years) & $22.8 \pm 8.5$ & $21.89 \pm 9.9$ & $23.3 \pm 8.9$ & $22.7 \pm 9.1$ \\
Average family size (number) & $6.2 \pm 1.4$ & $5.7 \pm 1.8$ & $5.3 \pm 1.4$ & $5.6 \pm 1.6$ \\
Average land size (ha) & $0.3 \pm 0.1$ & $0.3 \pm 0.1$ & $0.5 \pm 0.2$ & $0.4 \pm 0.2$ \\
\hline
\end{tabular}

The average family size of the respondents ranged from two to ten persons per household, with an average family size of six, which exceeds the average family size of the country by about 31\% [41]. This indicates there are many dependents in the family, and any negative impact on agriculture might lead to food insecurity in the study area. Similarly, a study by Belay and Manig [42] revealed that in eastern Ethiopia, the average family dependency ratio was 1.52 , i.e., more than one economically inactive person is supported by each economically active person in the family. The average farm size of the studied districts was $0.38 \mathrm{ha}$, which is much less than the national landholding size of 0.95 ha [43]. The small average landholding could be attributed to the rapidly increasing population that leads to increasing demand for land by newly formed households, leading to land fragmentation due to the need for redistribution of land among children. Consistent with this suggestion, Shumetie and Alemayehu [44] stated that the West Hararghe Zones of the Oromia Regional State is one of the most densely populated zones of the country and each farmer owns a very small plot of land.

\subsection{Farmers' Perception of Climate Change and Its Causes}

All sampled households in the study district perceived at least one aspect of temperature and rainfall change (Figure 3). The majority (78\%) of the interviewed households perceived increasing in temperature. However, $7 \%$ of the households perceived decrease in temperature, and the remaining ones perceived no change.

A decrease in rainfall amount was also perceived by most maize farmers, whereas $10 \%$ perceived no change, and the remaining 7\% perceived an increasing trend in this variable. Consistent with this suggestion, Jiri et al. [45] reported that more than $87 \%$ and $86 \%$ of the respondents perceived increases in average temperature and decrease in precipitation in the past 10-20 years in the Chiredzi district, Zimbabwe. Additionally, studies [13,46] reported that most of the interviewed farmers perceived increasing temperatures and decreasing amounts of rainfall in southern Ethiopia. Asrat and Simane [47] also reported that 
more than $50 \%$ of the respondents perceived increase in temperature while $42 \%$ and $25 \%$, respectively, perceived no change and decreasing temperature. Regarding precipitation, in northwestern Ethiopia, about $64 \%$ of the respondents indicated decrease in the rainfall amount while $34 \%$ of them perceived increase in rainfall amount.

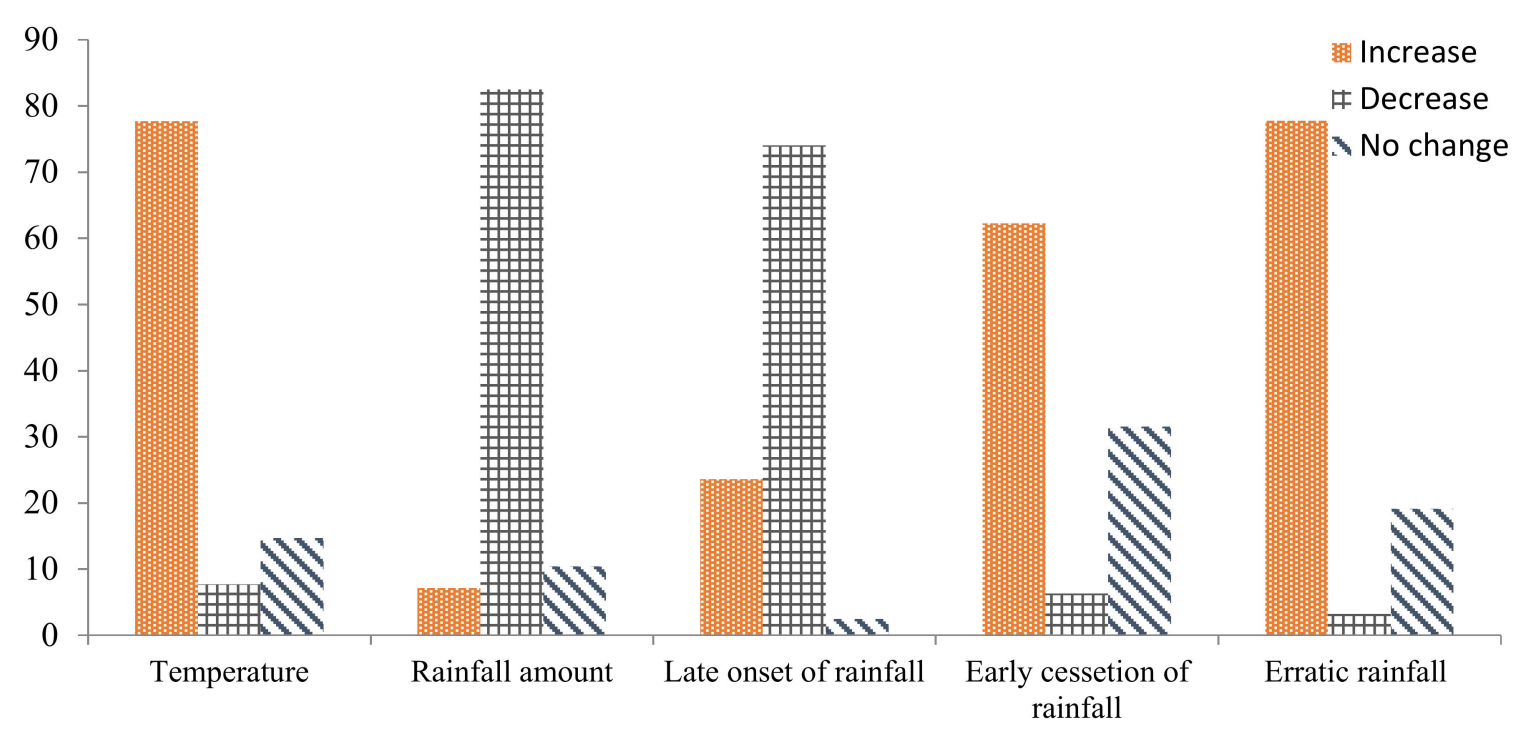

Figure 3. Farmers' perception of temperature and rainfall change and variability in the Eastern Highlands of Ethiopia $(N=364)$.

In this study, most farmers perceived increasing rainfall variability in terms of lateonset and early cessation rainfall during the main growing season (Figure 3). During the focus group discussion, farmers mentioned late-onset and early cessation of rainfall as a major factor that affects decisions on planting as well as harvesting dates. Consistent with this suggestion Bewket [48] reported that any change in the crop-growing period is a challenge as it considerably affected farmers' decisions on what and when to plant. Similarly, $[49,50]$ stated that late-onset, early cessation, and poor distribution of rainfall affected crop production significantly in the western Amhara region and north-central Ethiopia. Belay [32] also stated that during the main rainy season, in the Central Rift Valley region of Ethiopia, some farms were left uncultivated due to late-onset and low amounts of rainfall. Similarly, [44] reported that early cessation of rainfall was the most frequent type of rainfall variability, even before the crop grain-filling stages in the West Hararghe Zone.

\subsubsection{Farmers' Perceptions of Climate Change and Meteorological Data}

The majority of farmers in the study districts responded that there was decrease in rainfall amounts and increase in the temperature in the last thirty years (Figure 3). Meteorological data of rainfall in the main growing seasons showed a decreasing trend which was not statistically significant except for February in Haramaya and Chiro districts. Increasing trends were observed for maximum and minimum temperatures except for the maximum temperature in Chiro. Hence, the analysis of the meteorological data confirmed that the change in rainfall and temperature in the study districts showed decreasing and increasing trends, respectively. However, the differences were non-significant. This may be ascribed to farmers' perception of the inter-annual variability of climate parameters as climate change (Table 5 and Figure 4). Similarly, Amadou et al. [51] reported that farmers' perception of climate change did not tally with the recorded climate data even though the trend in the rainfall pattern during the last 50 years showed a remarkable decreasing trend. The rainfall data were not significant due to the high inter-annual variability. Consistant with this result, Esayas et al. [52] reported that farmers' perception about rainfall in the midland agro-ecological zone contradicted result of meteorological analysis. 

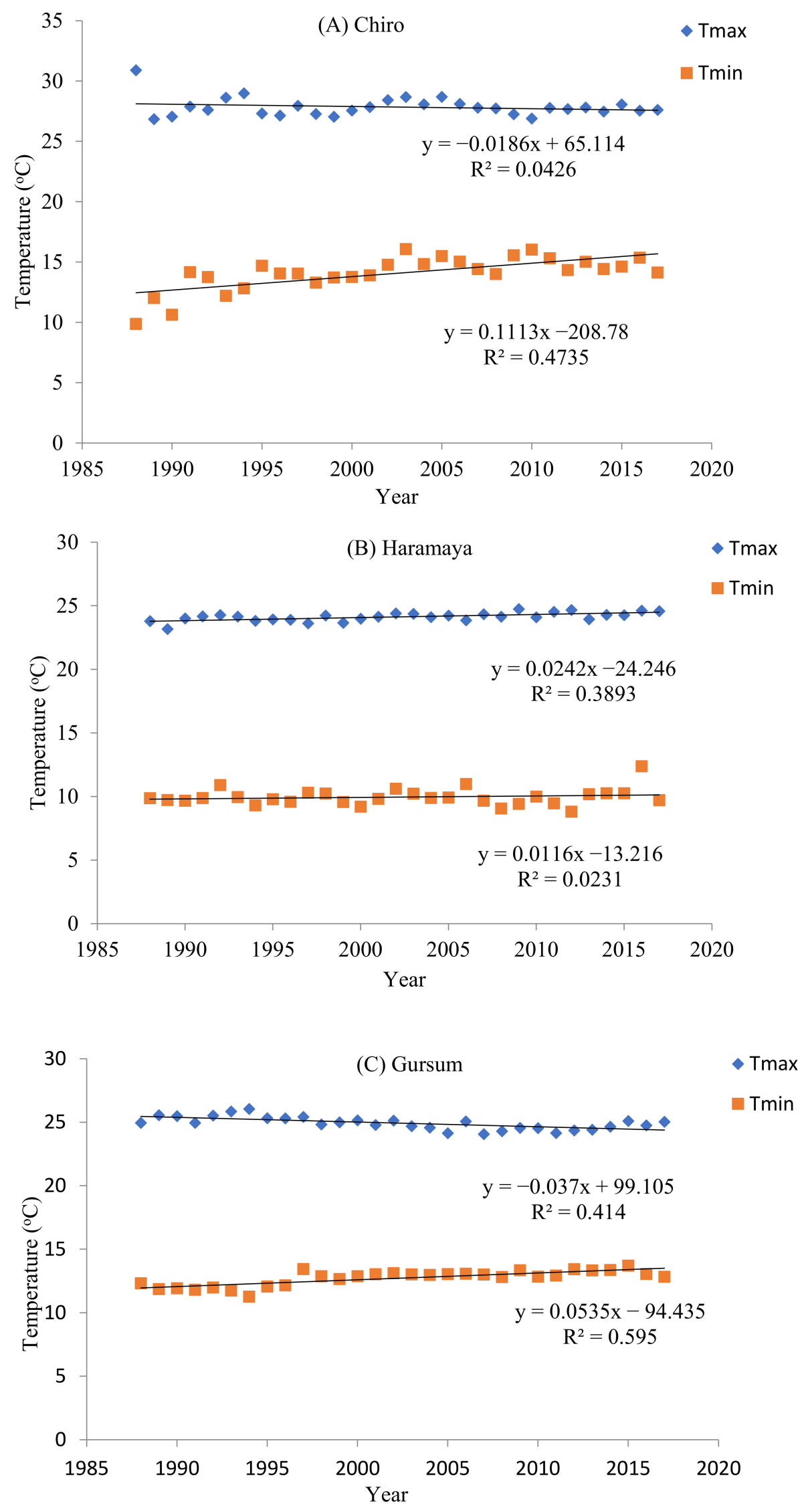

Figure 4. Mean annual minimum (Tmin) and maximum temperature (Tmax) trends of (A) Chiro (B) Haramaya, and (C) Gursum districts in the eastern highlands of Ethiopia (1988-2017). 
Table 5. Sen's slope values for monthly rainfall in the Belg and Kiremit seasons in eastern highlands of Ethiopia (1988-2017).

\begin{tabular}{cccccccccc}
\hline \multirow{2}{*}{ Stations } & \multicolumn{9}{c}{ Month } \\
\cline { 2 - 9 } & Feb & Mar & Apr & May & Jun & Jul & Aug & Sep \\
\hline Chiro & 0.00 & -1.84 & -1.77 & 1.10 & 0.40 & -2.07 & 0.79 & 1.44 \\
Gursum & $0.00^{*}$ & -1.52 & -1.28 & -0.12 & -0.50 & 0.44 & 0.21 & -0.46 \\
Haramaya & $-0.44^{*}$ & -1.46 & -0.72 & 1.47 & -0.20 & 2.53 & 0.77 & 1.15 \\
\hline
\end{tabular}

* = significant at $5 \%$ probability level.

\subsubsection{Factors Affecting Farmers' Perception of Change in Temperature and Rainfall}

The result of the multinomial logit regressions showed that age, educational level, family size, and access to extension services were the main factors significantly influencing farmers' perception of temperature and rainfall in the study area (Table 6). Empirical studies indicated that socio-economic and institutional variables influence farmers' perceptions of climate change. In line with this result, Agwu et al. [53] reported that age, education level, and household size were the main factors significantly influencing farmers' perception of climate change and the cultivation of the Garcinia kola in Nigeria. Similarly, according to Gbetibouo [54], education, age, and access to extension services were found to influence significantly farmers' perception of climate change in Limpopo River Basin.

Table 6. Results of the multinomial regression model of farmers' perception of changes in temperature and rainfall.

\begin{tabular}{ccc}
\hline Variable & Perceived Change in Temperature & Perceived Change in Rainfall \\
\hline Sex & 0.024 & -0.911 \\
Age & 0.005 & $0.103^{* * *}$ \\
Education level & $-0.562^{*}$ & $-0.868^{* *}$ \\
Land size & 0.411 & 0.076 \\
Family size & $-0.183^{*}$ & -0.170 \\
Access to extension service & $0.541^{*}$ & $0.592^{*}$ \\
Access to irrigation water & 0.296 & -0.477 \\
Haramaya & 0.359 & -0.310 \\
Gursum & -0.370 & -0.113 \\
Chiro & 0.096 & 0.373 \\
\hline
\end{tabular}

*** Significant at $1 \%$ level; ** significant at $5 \%$ level; ${ }^{*}$ significant at $10 \%$ level.

\subsubsection{Source of Information on Climate Change and Variability}

The majority of maize farmers were aware of climate change and variability from their own experience (Table 7). As shown in Table 4 above, the sampled households in the districts had an average farming experience of more than 20 years. This implies that the farming experience may help to observe the change in their surrounding environment. In line with this suggestion Belay et al. [32] showed that the majority of farmers perceived climate change through their life experience and understanding followed by development agents. Consistent with the results of this study, Tume et al. [55] also stated farmers value their ability to accurately observe and anticipate local conditions in various ways to serve existing realities more aptly than outside forecasts. Similarly, Singh [56] reported that farmers use their indigenous knowledge to perceive changes in climate and design adaptive farming practices. 
Table 7. Farmers' response to the source of information on climate change in the eastern highlands of Ethiopia $(N=364)$.

\begin{tabular}{ccc}
\hline Source of Information & Frequency & Percentage \\
\hline Own experience & 271 & 74.4 \\
Development agent & 237 & 65.1 \\
Fellow farmers & 136 & 37.4 \\
Media & 129 & 23.9 \\
\hline
\end{tabular}

\subsubsection{Perception of Farmers on the Causes of Climate Change and Variability}

Almost all (about 95.3\%) of maize farmers blamed deforestation as a major contributor to climate change and variability (Table 8 ). The remaining farmers blamed land-use change, natural phenomena, burning of fossil fuels as contributors to climate change and variability. A few other farmers attributed climate change and variability to the "Wrath of God".

Table 8. Farmers' perception of the causes of climate change and variability in the eastern highlands of Ethiopia $(N=364)$.

\begin{tabular}{ccc}
\hline Cause of Climate Change and Variability & Frequency & Percentage \\
\hline Deforestation & 347 & 95.3 \\
Land-use change & 124 & 34.1 \\
Natural phenomenon & 41 & 22.3 \\
Burning of fossil fuel & 35 & 9.6 \\
Wrath of God & 16 & 4.4 \\
\hline
\end{tabular}

During the focus group discussion, the respondents stated that the shortage of farmland as a result of population pressure and lack of alternative energy sources were the main motivating factors for deforestation. Consistent with the result of this study, Debela et al. [57] reported that farmers blamed supernatural forces (45\%), natural processes (33\%), and deforestation due to human action (16\%) for the occurrence of climate change. In line with this result, Yamba et al. [58] also identified deforestation as a key contributor to climate change as a consequence of agricultural expansion caused by population pressure.

The results of this study have also revealed the farmers did not blame the use of farm inputs such as applications of mineral fertilizer, farmyard manure, agrochemicals, burning of crop residues, etc. as a contributor to increasing greenhouse gas in the atmosphere. This may be attributed to the fact that perceiving climate change as a result of practicing such agricultural activities, without providing empirical evidence, will not be easy for the farmers. However, the evidence that farmers attribute climate change mainly to natural phenomena such as the "Wrath of God" would justify providing them with awareness on agricultural activities carried out to improve productivity.

\subsection{Perceived Impact of Climate Change and Variability on Maize Production}

\subsubsection{Drought/Water Source Reduction}

Drought was perceived to be one major impact of climate variability and change on maize production by the majority of respondents in Gursum district, followed by those in Chiro and Haramaya districts as the climatic condition of the study districts are different (Table 9). Farmers also lamented the limitation of water as a result of unpredictable weather caused by shortage or irregularity of rainfall and variability in temperature in the area. In line with the results of this study, studies $[59,60]$ have shown changes in precipitation combined with rising temperatures adversely influenced the availability of soil moisture and caused droughts. Corroborating this result, Wang et al. [61] also reported that increasing frequency and intensity of drought had a negative influence on maize production. 
Table 9. Farmers' perceived impacts of climate change and variability on maize production in the eastern highlands of Ethiopia $(N=364)$.

\begin{tabular}{ccccccc}
\hline \multirow{2}{*}{ Climate Change Impact } & \multicolumn{2}{c}{ Chiro } & \multicolumn{2}{c}{ Haramaya } & \multicolumn{2}{c}{ Gursum } \\
\cline { 2 - 7 } & Frequency & $\mathbf{( \% )}$ & Frequency & $\mathbf{( \% )}$ & Frequency & (\%) \\
\hline Drought/water source reduction & 38 & 30.9 & 47 & 51.7 & 87 & 70.7 \\
Reduction in crop yield & 49 & 32.8 & 29 & 31.9 & 58 & 43.9 \\
Loss of soil fertility & 85 & 63.3 & 52 & 34.7 & 75 & 60.9 \\
Increased diseases and pests problem & 113 & 75.3 & 79 & 86.8 & 95 \\
\hline
\end{tabular}

\subsubsection{Reduction in Crop Yield}

It was noted that more than $40 \%$ of the farm households in Gursum district and $30 \%$ in Haramaya and Chiro districts acknowledged reductions in maize yields due to climate change and variability (Table 9). The most perceptible climatic factors that affected maize production in all study districts were increasing temperatures, insufficient and erratic rainfall as well as variability in the date of onset and cessation of rainfall. When temperatures climb above the optimum for maize, which is 18 to $32{ }^{\circ} \mathrm{C}$, vegetative and reproductive growth of the plant is affected and yield can be reduced by as much as 80-90\% [62]. Similarly, erratic rainfall, late-onset as well as an early cessation of rainfall resulted in moisture stress and wilting in maize, thereby reducing its yield [63]. Consistent with this result, Jiri et al. [45] indicated that $76 \%$ of the farmers believed that maize yields declined due to reduction in rainfall amounts and the variability caused by drought and high temperatures in Chiredzi district, Zimbabwe. Chhogyel et al. [64] reported that maize yield suffered losses ranging from $10 \%$ to $20 \%$ as a result of unpredictable weather, less or no rain, high-intensity rains, drying up of irrigation sources, and the emergence of diseases and pests in Bhutan in the Himalayas. Consistent with the results of this study, Harvey et al. [65] also stated $87 \%$ of smallholder maize farmers in Central America experienced impacts of rising temperatures, unpredictable rainfall, and extreme weather events.

\subsubsection{Loss of Soil Fertility}

Loss of soil fertility was one of the impacts of climate change perceived by the smallholder maize farmers in the study area. The majority of the respondents in Chiro districts perceived dwindling soil fertility followed by those in Gursum and Haramaya districts (Table 9). During the focus group discussion, farmers mentioned that high rainfall intensity caused erosion of the fertile topsoil because the land is denuded of its vegetation cover and farmers remove biomass from the land for competing ends such as construction houses, source fuel for cooking, animal feed, etc. Farmers also implicated rising demand for fertilizer as an indicator of dwindling soil fertility. To counter the negative impact of climate change and increase maize production, the farmers have been applying mineral and organic fertilizer and practicing intercropping (maize with legume especially common bean). In line with this result, Hamidov et al. [66] reported that climate change increased soil erosion rates due to increased frequency of high-intensity rainfall events that negatively affected soil fertility. Additionally, Jackson et al. [67] stated that low soil fertility not only decreased crop yield, but it also increased household vulnerability to food insecurity.

\subsubsection{Disease and Pest Problems}

It was noted that more than $80 \%$ of farm households in Haramaya district, followed by those in Gursum and Chiro districts, perceived the impact of disease and pest problems as a result of climate change and variability (Table 9). This may be ascribed to favorable conditions created by the changes in rainfall and temperature for the proliferation of diseases and pests. The most serious insect pest of notoriety mentioned by farmers was the fall armyworm (Spodoptera frugiperda) that has threatened maize production in recent years in the region. This result is supported by the finding of Naveenkumar et al. [68] that revealed climate change affected the diversity and responsiveness of agricultural pests and diseases and accounted for a significant proportion of maize yield losses worldwide. 
Consistent with this suggestion, Richard et al. [69] also noted that incidences of insect pests (stem borer and armyworm) increased as a result of climate change and variability.

\subsection{Adaptation Approach and Barriers to Adaptation}

\subsubsection{Adaptation Strategies Used by Smallholder Maize Farmers}

The interviewed maize farmers, who perceived climate change in terms of increasing temperature, reduced/change in rainfall characteristics, revealed they were using some adaptation strategies to reduce the impact of climate change on maize production. The study identified six major climate change adaptation strategies implemented by smallholder maize farmers in the districts (Figure 5).

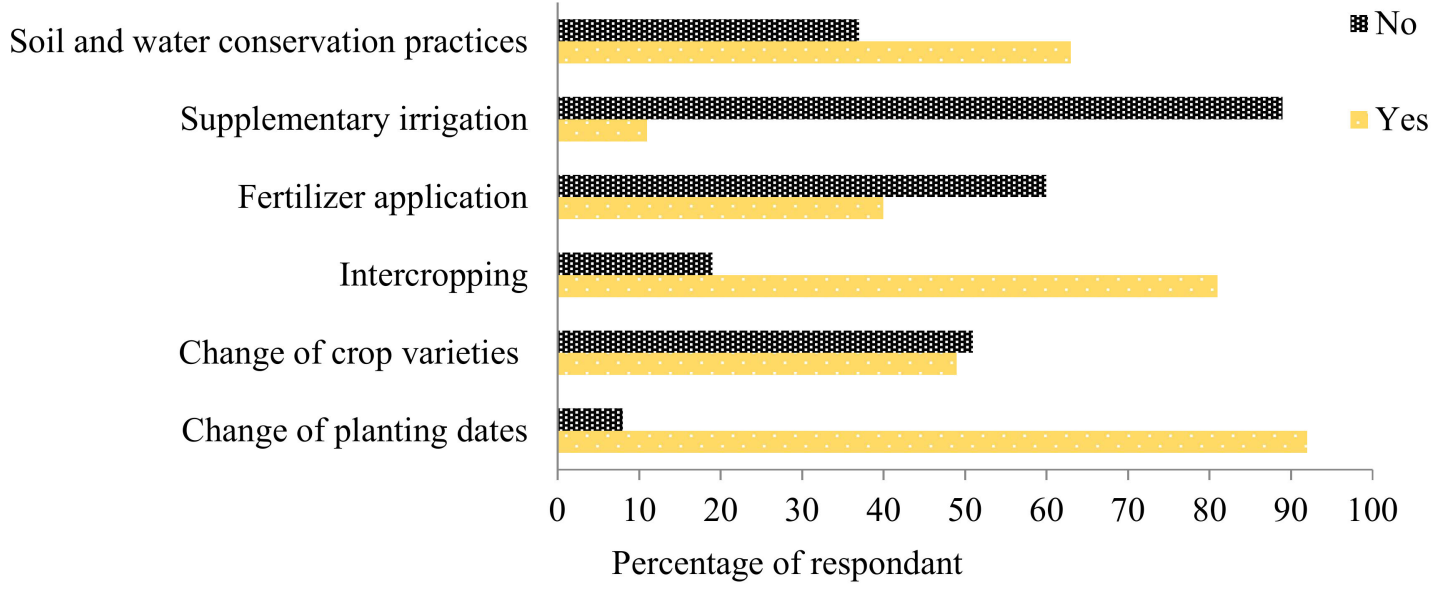

Figure 5. Adaptation strategies used by smallholder maize farmers in the Eastern highlands of Ethiopia $(N=364)$.

Changing Planting Date and Varieties

The majority of the farmers revealed that they changed planting dates in response to early or late-onset dates of rainfall in the districts studied. This indicates maize farmers do not plant at the same periods of the year. Instead, they plant the crop as soon as the rain starts. This strategy is a response to the delay/early onset of the rains in recent times which often led to changes in harvest time as well. The second adaptation strategy used in the study area was the use of improved high-yielding maize varieties that are resistant to biotic and abiotic stresses. Consistent with this observation, studies [13,32] showed that to reduce the impacts of climate change and obtain high yields, changing planting dates and varieties were practiced frequently by maize farmers in central and southern Ethiopia. The use of improved maize varieties has increased in Ethiopia in general and in the eastern highlands of the country, in particular, as a response to climate change. For instance, between 2004 and 2013 , the maize area planted with improved varieties increased from $14 \%$ to $40 \%$ in the country [70].

Intercropping

Intercropping is an adaptation strategy practiced by maize farmers in the study area. Farmers intercrop maize mostly with common bean (Phaseolus Vulgaris L.), sweet potato (Ipomoea batatas), and Khat (Catha edulis Forsk). During the focus group discussion and key informant interviews, the farmers revealed that land shortage, income diversification/risk reduction, and soil fertility improvement were the major reasons for intercropping. Intercropping with legumes can reduce the requirements for fossil-based nitrogen fertilizer by about $26 \%$ on a global scale [71]. In agreement with this suggestion, Mohammed et al. [72] indicated that in the East Hararghe Zone, farmers intercrop major cereal crops (maize, and sorghum) with legumes, such as common beans (Phaseolus vulgaris). Similarly, Shumetie and Alemayehu [44] also reported that households in the West Hararghe Zone cope with 
the problem of land shortage through intercropping. Similarly, Chichongue et al. [73] reported that intercropping maize with legume crops was adopted to maximize land use and reduce the risk of crop failure. In this connection, Fung et al. [74] stated that intercropping has been considered a sustainable practice that can reduce the impact of climate change in agriculture.

\section{Recommended Mineral Fertilizer Application}

In the study area, more than $40 \%$ of farm households applied mineral fertilizers to increase the yield of maize. However, according to the information obtained from the agricultural development offices in the respective kebeles, most of the maize farmers use less than half of the rate of fertilizer recommended for maize production in the area due to lack of access, untimely supply as well as unaffordability of the fertilizers. However, the application of organic fertilizer is limited, even if it has potential to reduce the demand for mineral fertilizers which increase the concentration of greenhouse gases in the atmosphere. Similarly, Abate et al. [70] stated that the application of mineral fertilizer for maize production increased while the use of organic fertilizer declined between 2004 and 2013.

\section{Supplementary Irrigation and Soil and Water Conservation}

The maize farmers mostly depended on rainfall for producing the crop and very few used supplementary irrigation as an adaptation strategy. During the focus group discussion, farmers indicated lack of access to irrigation water, dwindling irrigation water, as well as the unaffordability of water motor pumps and fuel as barriers to using supplementary irrigation for producing maize. Shortage of water is common in eastern Ethiopia in general and the study districts in particular since there are few water bodies such as rivers, lakes, ponds, etc. The only alternate source of water during the dry season is well water that farmers may strike by digging into the ground.

The best option for enhancing the availability of water in the area for intense agricultural activities would have been harvesting rainwater, which is plenty during the main rainy season. However, lack of know-how and technology prohibits this prospect of using rainwater for agricultural production in the area for year-round production of crops. Consistent with this result, Ndhleve et al. [75] reported that low/no rain throughout the season, delay or late onset of rainfall, and interruption in rainfall for a week or more in a season resulted in $75 \%, 54 \%$, and $50.5 \%$ losses in maize yield, respectively. Hence, farmers described the use of supplementary irrigation as a top-ranking adaptation strategy. Most of the maize farmers used soil and water conservation practices such as trenches, contour planting, terraces, and stone dams. In line with this result, Abera and Tesema [11] stated that soil and water conservation practices were the most adopted strategy in eastern Ethiopia.

\subsubsection{Factors Affecting Adaptation Strategies}

Before running the Multinomial Logit Model, the data were tested for the presence of multicollinearity in the data set. Among the variables hypothesized to influence adaptation strategies in the study area, correlation coefficients, which do not suggest the incidence of strong collinearity, were dropped from the model. According to Shrestha [76], if the correlation coefficient is greater than 0.7 , collinearity is very likely to exist. Hence, in this study farming experience which has a lower correlation coefficient than age was dropped. In addition, we have not considered sex as an independent variable because the number of female-headed households was less than 10\% (Section 3.1), which is not comparable for analyses to allow conclusions on the farmers' perceptions of climate change and adaptation strategies.

The result of IIA assumptions using Hausman's test failed to reject the null hypothesis of independence. Therefore, the application of the MNL specification was appropriate to model climate change adaptation practices. The model was run taking 'no adaptation' as the base category in which the remaining outcomes were compared. The farmers indicated 
several barriers to implementing proper adaptation strategies such as age, low education level, small farm size, family size, lack of access to credit, lack of access to irrigation water, and lack of access to extension services (Table 10).

Age

The age of the household head affects adaptation strategies to climate change. In this study, the age of the household head positively impacted all of the adaptation practices used in the districts except recommended mineral fertilizer application. The negative association of age with that of recommended mineral fertilizer application may be due to the fact that aged household heads are reluctant to apply mineral fertilizer, instead, preferring the application of organic or less than the recommended amounts (sub-optimal level) of mineral fertilizers. Consistent with this result Erena and Gemechu [77], age negatively affected mineral fertilizer application as a result of aged people's hesitation to apply mineral fertilizers in southeastern Ethiopia. Consistent with this suggestion, Tazeze et al. [78] also reported that the higher the age of the household head, the better the know-how the person possesses, which helped him/her to practice various adaptation strategies to climate change. Corroborating this suggestion, Tume et al. [55] stated local farmers' ability to make informed decisions is largely governed by personal experiences acquired over the years.

Table 10. Multinomial regression model result of adaptation strategies $(N=364)$.

\begin{tabular}{|c|c|c|c|c|c|c|}
\hline Variables & $\begin{array}{c}\text { Adjusting } \\
\text { Planting Date }\end{array}$ & $\begin{array}{c}\text { Changing } \\
\text { Maize Variety }\end{array}$ & $\begin{array}{c}\text { Inter- } \\
\text { Cropping }\end{array}$ & $\begin{array}{c}\text { Rec. Mineral } \\
\text { Fertilizer } \\
\text { Application }\end{array}$ & $\begin{array}{l}\text { Supplemental } \\
\text { Irr. }\end{array}$ & $\begin{array}{l}\text { Soil and Water } \\
\text { Conservation }\end{array}$ \\
\hline & Coeff. & Coeff. & Coeff. & Coeff. & Coeff. & Coeff. \\
\hline Age & 0.027 & 0.010 & 0.013 & -0.011 & 0.008 & 0.013 \\
\hline Education level & -0.633 & -0.163 & 0.199 & $-0.271 *$ & 0.105 & 0.066 \\
\hline Farm size & -0.181 & $2.081 * *$ & $1.362 *$ & 0.964 & -0.825 & -0.410 \\
\hline Family size & $-0.269 *$ & -0.064 & $0.156 *$ & 0.093 & 0.010 & 0.049 \\
\hline Access to irr. Water & -1.595 & 0.626 & 0.333 & 0.026 & $4.407^{* * *}$ & -0.196 \\
\hline Access to ext. service & 0.691 & $4.172 * * *$ & $-1.107^{* * *}$ & $3.010^{* * *}$ & -0.100 & 0.049 \\
\hline Haramaya & -0.146 & -0.354 & 0.223 & 0.136 & $1.450 * * *$ & $0.562 * *$ \\
\hline Gursum & -0.033 & -0.188 & -0.736 & 0.270 & -0.512 & -0.247 \\
\hline Chiro & 0.149 & $0.447^{* *}$ & $0.575^{* *}$ & -0.360 & $-1.013^{* *}$ & -0.184 \\
\hline
\end{tabular}

Irr. = irrigation; ext. = extension; Rec. = Recommended; Coeff. = coefficient; ${ }^{* * *}$ Significant at $1 \%$ level; ${ }^{* *}$ significant at $5 \%$ level; ${ }^{*}$ significant at $10 \%$ level.

\section{Education Level}

The result of the study indicated that the education level of the household head had a negative association with adjusting planting date, changing maize variety for cultivation, and fertilizer application in the study districts. Additionally, the negative relationship is significant $(p<0.05)$ with recommended mineral fertilizer application. This could be attributed to the fact that illiterate households are in the category older ages, who prefer to apply organic sources of fertilizer than mineral fertilizer for maize production. Those households mostly engaged in sustainable crop production practices with less attention to immediate benefits. Consistent with this suggestions, Abebe and Debebe [79] reported that illiterate households prefer to apply organic sources of fertilizers as compared with educated households for crop production. In contrast, a positive association of education level was obtained with intercropping, supplementary irrigation, and soil and water conservation adaptation strategies. This indicated that the education level of farm households plays a role in using diverse adaptation strategies as farmers can collect information from different sources. In addition, negative associations may be due to the fact that smallholder farmers' farming experience plays a key role in climate change perception which leads to adaptation strategies that have been stated (Table 6). Consistent 
with this suggestion, Jiri et al. [45] also stated that a farmer's adaptation options could be determined by their state of farming experience.

\section{Farm Size}

Farm size had a positive and significant $(p<0.01)$ and $(p<0.05)$ influence on maize variety change and intercropping while it had a non-significant positive influence on the recommended mineral fertilizer application by maize farmers in the study area. Farm size is negatively correlated with planting date adjustment, supplementary irrigation, and soil and water conservation. This indicates that farmers with large-sized farms have better opportunities to plant more varieties of the crop whereas those with small-sized ones have lower opportunities as they are limited by the sheer size of the land. However, other adaptation practices that are not associated with farm size may require more labor to adapt independently of land size, which is expensive and unaffordable to farmers with large-sized farms. This suggestion is in agreement with the findings of [44] who stated that a household that has relatively large-sized croplands may have a higher probability of adopting improved maize varieties as a means of mitigating the negative effect of delayed and inadequate rainfall. Consistent with this suggestion, Phillipo et al. [80] explained that households with small landholdings were more likely to choose commonly used crop varieties because of extra costs associated with acquiring new crop varieties.

\section{Family Size}

Family size had a positive influence on the use of intercropping, recommended mineral fertilizer application, supplementary irrigation, and soil and water conservation. Thus a larger family size can implement labor-intensive adaptation measures. In line with this result, Silvestri et al. [81] argued that having a large family would enable households to have more labor to carry out different farm activities. Similarly, [55,82] showed that a larger family size enabled farmers to take up labor-intensive climate change adaptation measures such as soil and water conservation and irrigation would that demand labor especially during the peak periods of activities. In contrast, Tazeze et al. [78] argued households with a large family size may be lured into diverting part of the labor force to off-farm activities in an attempt to earn additional income and reduce the consumption pressure imposed by a large family rather than adopting improved crop varieties and others.

\section{Access to Irrigation Water}

In this study, access to irrigation water was positively and significantly $(p<0.01)$ associated with the use of supplementary irrigation by smallholder farmers in the area. Access to irrigation water is beneficial to off-season maize production and to supplement when rainfall is insufficient to provide essential soil moisture to secure a good harvest. A household with access to irrigation water plants high yielding maize varieties and applies fertilizer on time. Similarly, Arragaw and Woldeamlak [12] claimed that a shortage of water for irrigation was the major barrier to effectively use different adaptation strategies, including high-yielding crop varieties.

\section{Access to Extension Services}

Access to extension service had positive and significant associations with all adaptation practices except intercropping using supplementary irrigation however significant with changing maize variety and recommended mineral fertilizer application $(p<0.01)$. in the study area. This implies that information on weather helps to plant at the optimum time, selecting varieties that are suitable for the environment, deciding on what type of fertilizer and when to apply it, etc. However, intercropping and soil and water conservation being done in the study area as a common practice to diversify crops and to reduce land degradation then soil fertility reduction, respectively. Similarly, a study by Sorech [83] in selected rural kebeles of Chiro district, Hararghe, Ethiopia stated that lack of timely and easily accessible information on the weather forecast and adaptation options 
were the major challenges. In line with this result, Ayalew [49] reported that information related to forecasting climate change, adaptation options, and other agricultural production activities is a vital factor influencing the use of different adaptation measures for most farmers. Similarly, Vaughan and Hansen [84] also stated that meteorological information is very important for farmers that depended on rain-fed agriculture to improve agricultural productivity and increase income, thereby reducing the impacts of climate change and minimizing risks.

\section{Study Districts}

Climate change adaptation practices such as changing maize variety, intercropping, applying supplementary irrigation, and soil and water conservation significantly $(p<0.05)$ varied across the study districts. In Haramaya district, smallholder maize farmers practiced supplementary irrigation and soil and water conservation practices more significantly than those in the other study districts. This may be attributed to the existence of water bodies such as Haramaya Lake and Tinique Lake nearby, which enhances their accessibility to irrigation water from both lakes as well as from groundwater. Research and community services held by Haramaya University across the lake watershed may have also contributed to the use of the above-mentioned climate change adaptation strategies. On the other hand, Chiro, farmers practiced intercropping and changed maize variety more significantly than the other study districts. This may be attributed to the proximity of the district to central markets such as Adama and Addis Ababa. A significant negative association of supplementary irrigation in Chiro also may indicate a lack of accessibility to irrigation water in this district.

\section{Access to Credit}

In the study area, there is no credit service. Farmers revealed that high costs are the major factors that hinder them from acquiring improved seed and fertilizer. As a result, they apply sub-optimal rates of fertilizers which are far below the recommended rates. Similarly, studies have shown that access to credit increases the likelihood of adaptation. Consistent with this suggestion, the studies in $[42,65]$ also stated access to credit service is an important factor to narrow the financial gaps of farmers so that they could purchase the required farm inputs and technologies useful for improving agricultural production and reduce climate change impact.

During the focus group discussion, farmers showed interest in employing most of the adaptation options; however, supports from governmental and non-governmental organizations in terms of availing the required amounts and types of farm input, credit services, and technical supports are minimal.

\section{Conclusions}

The results of the study showed that farmers perceived increase in temperature and rainfall variability and decrease in the amounts of rainfall. The highest percentages of the farmers were aware of climate change and variability from their own experience and blamed deforestation as a major cause. Farmers identified decreasing yields, dwindling soil fertility, increased incidences of pests and disease, and drought as major constraints they face in producing maize. Hence, changing planting dates, increasing the use of abiotic and biotic stress-tolerant maize varieties, supplementary irrigation, intercropping, applying recommended rates of mineral fertilizers, and taking soil and water conservation measures helped them adapt to climate change. The major factors which influenced farmers' climate change perception and adaptation practices included age, education level, farm size, family size, access to water for irrigation, and access to extension service.

The results of the study imply that farmers have become aware of climate change and its consequences as a result of which they have been attempting to counter its effects and maintain the productivity of maize through adopting various strategies. However, socio-economic barriers are limiting their efforts. Therefore, to enhance smallholder maize 
farmers' adaptive capacity and build resilience to climate change in the eastern highlands of Ethiopia, agricultural policymakers should focus on putting in place enabling policies. Both governmental and non-governmental organizations should support farmers by building their capacity and enhancing their access to irrigation water, particularly through climatesmart water harvesting technologies, improved maize varieties that adapt to the changing climate and local conditions, information on weather forecasts, and inputs such as fertilizers, and agro-chemicals. Future research in the study area should focus on developing droughttolerant high-yielding maize varieties, optimizing rainwater harvesting systems to enhance small-scale irrigation, and formulating site-specific sustainable fertilizer (organic and mineral) and irrigation rates to optimize yields of various maize varieties under smallholder farming conditions.

Author Contributions: H.T. worked on data collection, data analysis, and writing —original draft; K.T., N.D., T.T. and M.H. helped in result interpretation and write-up. All authors have read and agreed to the published version of the manuscript.

Funding: Africa Center of Excellence for Climate Smart Agriculture and Biodiversity Conservation, Haramaya University, Ethiopiaas part of a research study.

Institutional Review Board Statement: Not applicable.

Informed Consent Statement: Not applicable.

Data Availability Statement: Not applicable to this article as there is no data were created.

Acknowledgments: The authors thank farmers, agricultural development agents and local administrators in the East and West Hararghe Zones and Ethiopian National Meteorological Agency (ENMA) for proving the information needed for this study.

Conflicts of Interest: The authors declare no conflict of interest.

\section{References}

1. Alemu, T.; Mengistu, A. Impacts of Climate Change on Food Security in Ethiopia: Adaptation and Mitigation Options: A Review: Soil-Water-Plant Nexus. In Climate Change-Resilient Agriculture and Agroforestry; Springer: Berlin/Heidelberg, Germany, 2019; pp. 397-412. [CrossRef]

2. Matewos, T. Climate change-induced impacts on smallholder farmers in selected districts of Sidama, Southern Ethiopia. Climate 2019, 7, 70. [CrossRef]

3. Assan, E.; Suvedi, M.; Schmitt, O.L.; Allen, A. Coping with and Adapting to Climate Change: A Gender Perspective from Smallholder Farming in Ghana. Environments 2018, 5, 86. [CrossRef]

4. FAO. Food Loss Analysis: Causes and Solutions; FAO: Rome, Italy, 2018.

5. FAO; IFAD; UNICEF; WFP; WHO. The State of Food Security and Nutrition in the World; Building Resilience for Peace and Food Security; FAO: Rome, Italy, 2017.

6. Abate, T.; Fisher, M.; Abdoulaye, T.; Kassie, G.T.; Lunduka, R.; Marenya, P.; Asnake, W. Characteristics of maize cultivars in Africa: How modern are they and how many do smallholder farmers grow? Agric. Food Secur. 2017, 6, 30. [CrossRef] [PubMed]

7. Keno, T.; Azmach, G.; Wegary, D.; Worku, M.; Tadesse, B.; Wolde, L.; Deressa, T.; Abebe, B.; Chibsa, T.; Suresh, L.M. Major biotic maize production stresses in Ethiopia and their management through host resistance. Afr. J. Agric. Res. 2018, 21, 1042-1052. [CrossRef]

8. Tesfaye, K.; Gbegbelegbe, S.; Cairns, J.E.; Shiferaw, B.; Prasanna, B.M.; Sonder, K.; Boote, K.; Makumbi, D.; Richard, R. Maize systems under climate change in sub-Saharan Africa. Int. J. Clim. Chang. Strateg. Manag. 2015, 3, 247-271. [CrossRef]

9. Apata, T. Factors influencing the perception and choice of adaptation measures to climate change among farmers in Nigeria Evidence from farm households in Southwest Nigeria. Environ. Econ. 2011, 4, 74-83.

10. Atchkipa, M.T.; Adzawla, W.; Yegbemey, R.N.; Diallo, M.; Aman, N. A Determinants of Farmer's Perception and Adaptation to Climate Change: The Case of Maize and Sorghum Farmers in Benin and Nigeria. Int. J. Sci. Res. Rev. 2017, 6, $227-243$.

11. Abera, N.; Tesema, D. Perceptions and practices of climate change adaptation and mitigation strategies among farmers in the Konta Special District, Ethiopia. Environ. Socio-Econ. Stud. 2019, 7, 1-16. [CrossRef]

12. Arragaw, A.; Woldeamlak, B. Smallholder farmers' coping and adaptation strategies to climate change and variability in the central highlands of Ethiopia. Int. J. Justice Sustain. 2017, 22, 825-839. [CrossRef]

13. Sisay, B.B.; Vanhove, W.; Wordofa, M.G.; Natarajan, K.; Van Damme, P. Perception of and response to climate change by maize-dependent smallholders. Clim. Res. 2018, 75, 261-275. [CrossRef]

14. Mazengia, Y. Smallholders Commercialization of Maize Production in Guangua District, northwestern Ethiopia. World Sci. News 2016, 58, 65-83. 
15. Burney, J.; Cesano, D.; Russell, J.; Rovere, E.L.; Corral, T.; Coelho, N.S.; Santos, L. Climate change adaptation strategies for smallholder farmers in the Brazilian Sertão. Clim. Chang. 2014, 126, 45-59. [CrossRef]

16. Daba, M.H. Assessing Local Community Perceptions on Climate Change and Variability and its Effects on Crop Production in Selected Districts of Western Oromia, Ethiopia. J. Climatol. Weather Forecast. 2018, 6, 216. [CrossRef]

17. Tafesse, A.; Ayele, G.; Ketema, M.; Geta, E. Adaptation to Climate Change and Variability in Eastern Ethiopia. J. Econ. Sustain. Dev. 2016, 1700, 91-104. [CrossRef]

18. Ahmed, B. What Factors Contribute to the Smallholder Farmers Farm Income Differential? Evidence from East Hararghe, Oromia, Ethiopia. J. Asian Sci. Res. 2016, 6, 112-119. [CrossRef]

19. Yibekal, A.T.; Aweke, C.S.; Endris, G.S. Understanding the process of adaptation to climate change by small-holder farmers: The case of east Hararghe Zone, Ethiopia. Agric. Food Econ. 2013, 1, 1-13. [CrossRef]

20. Yamane, T. Statistics: An Introductory Analysis, 2nd ed.; Harper andRow: New York, NY, USA, 1967.

21. Stern, R.; Rijks, D.; Dale, I.; Knock, J. Instat Climatic Guide; Statistical Services Centre, the University of Reading: Reading, UK, 2006.

22. Ngongondo, C.; Xu, C.Y.; Gottschalk, L.; Alemaw, B. Evaluation of spatial and temporal characteristics of rainfall in Malawi: A case of the data-scarce region. Theor. Appl. Climatol. 2011, 106, 79-93. [CrossRef]

23. Alexandersson, H. A homogeneity test applied to precipitation data. J. Climatol. 1986, 6, 661-675. [CrossRef]

24. Buishand, T.A. Some methods for testing the homogeneity of rainfall records. J. Hydrol. 1882, 58, 11-27. [CrossRef]

25. Pettitt, A.N. A Non-Parametric Approach to the Change-Point Problem. J. R. Stat. Soc. Ser. C 1979, 28, 126-135. [CrossRef]

26. Neumann, J. Distribution of the Ratio of the Mean Square Successive Difference to the Variance. Ann. Math. Stat. 1941, 12, 153-162. [CrossRef]

27. Storch, H. Misuses of Statistical Analysis in Climate Research. In Analysis of Climate Variability; Von Storch, H., Navarra, A., Eds.; Springer: Berlin/Heidelberg, Germany, 1995. [CrossRef]

28. Partal, T.; Kahya, E. Trend analysis in Turkish precipitation data. Hydrol. Process. 2006, 20, 2011-2026. [CrossRef]

29. Mann, H.B. Nonparametric Tests Against Trend. J. Econom. Soc. 1945, 13, 245-259. [CrossRef]

30. Kendall, M.G. Rank Correlation Methods, 4th ed.; Charles Griffin: London, UK, 1975.

31. Sen, P.K. Estimates of the Regression Coefficient Based on Kendall's Tau. J. Am. Stat. Assoc. 1968, 63, 1379-1389. [CrossRef]

32. Belay, A.; Recha, J.W.; Woldeamanue, T.; Morton, J.F. Smallholder farmers' adaptation to climate change and determinants of their adaptation decisions in the Central Rift Valley of Ethiopia. Agric. Food Secur. 2017, 6, 24. [CrossRef]

33. Greene, W. Econometric Analysis, 5th ed.; Prentice-Hall: Upper Saddle River, NJ, USA, 2002.

34. Hausman, J.; McFadden, D. Specification Tests for the Multinomial Logit Model. Econometrica 2014, 52, 1219-1240. [CrossRef]

35. StataCorp. Stata: Release 14. Statistical Software; StataCorp LP: College Station, TX, USA, 2015.

36. Frank, E. Gender, Agricultural Development and Food Security in Amhara, Ethiopia: The Contested Identity of Women Farmers in Ethiopia; USAID: Washington, DC, USA, 1999; pp. 1-20.

37. CSA (Central Statistical Agency). Agricultural Sample Survey 2016/2017(2009 E.C.): Volume I. Report on Area and Production of Major Crops (Private Peasant Holdings, Meher Season): Statistical Bulletin: 585, 2017, Addis Ababa, Ethiopia. Available online: https: / / www.statsethiopia.gov.et/our-survey-reports / (accessed on 10 September 2020).

38. Amare, A.; Simane, B. Determinants of smallholder farmers ' decision to adopt adaptation options to climate change and variability in the Muger Sub basin of the Upper Blue Nile basin of Ethiopia. Agric. Food Secur. 2017, 6, 64. [CrossRef]

39. Montle, B.P.; Teweldemedhin, M.Y. Assessment of farmers' perceptions and the economic impact of climate change in Namibia-A case study on small-scale irrigation farmers (SSIFs) of Ndonga Linena irrigation project. J. Dev. Agric. Econ. 2014, 6, 443-454. [CrossRef]

40. Tadesse, T.; Hassan, R.M.; Ringler, C.; Alemu, T.; Yesuf, M. Determinants of farmers' choice of adaptation methods to climate change in the Nile Basin of Ethiopia. Glob. Environ. Chang. 2009, 19, 248-255. [CrossRef]

41. CSA (Central Statistical Agency). Agricultural Sample Survey 2019/2020 (2012 E.C.) Volume 10, Report on Crop and Livestock Product Utilization (Private Peasant Holdings, Meher Season). Statistical Bulletin 588; Addis Ababa, Ethiopia, 2020. Available online: https: / / www.statsethiopia.gov.et/agriculture/forecast-agricultural-sample-survey/ (accessed on 21 March 2021).

42. Belay, K.; Manig, W. Access to rural land in Eastern Ethiopia: Mismatch between policy and reality. J. Agric. Rural Dev. Trop. Subtrop. 2004, 105, 123-138.

43. WFP/CSA (World Food Program Ethiopia Office and Central Statistical Agency of Ethiopia). Comprehensive Food Security and Vulnerability Analysis. Addis Ababa, Ethiopia, 2019. Available online: www.wfp.org (accessed on 28 December 2019).

44. Shumetie, A.; Alemayehu, M. Effect of climate variability on crop income and indigenous adaptation strategies of households. Int. J. Clim. Chang. Strateg. Manag. 2018, 10, 580-595. [CrossRef]

45. Jiri, O.; Mafongoya, P.; Chivenge, P. Smallholder Farmer Perceptions on Climate Change and Variability: A Predisposition for their Subsequent Adaptation Strategies. J. Earth Sci. Clim. Chang. 2015, 6, 277. [CrossRef]

46. Elias, B.; Ganewo, Z. Climate Change and Variability Effects on Maize (Zea mays L.) Production, and Farmers Perception in Halaba zone, Southern Ethiopia. J. Environ. Earth Sci. 2020, 10, 55-63. [CrossRef]

47. Asrat, P.; Simane, B. Farmers' perception of climate change and adaptation strategies in the Dabus watershed, North-West Ethiopia. Ecol. Process. 2018, 7, 7. [CrossRef]

48. Bewket, W. Climate change perceptions and adaptive responses of smallholder farmers in central highlands of Ethiopia. Int. J. Environ. Stud. 2012, 69, 507-523. [CrossRef] 
49. Ayalew, W. Analysis of Smallholder Farmers' Perceptions of Climate Change and Adaptation Strategies to Climate Change: The Case of Western Amhara Region, Ethiopia. Ph.D. Thesis, The University of South Africa, Pretoria, South Africa, 2016.

50. Rao, P.; Addisu, S. Trend Analysis and Adaptation Strategies of Climate Change in north central Ethiopia. Int. J. Agric. Sci. Res. 2013, 3, 253-262.

51. Amadou, M.L.; Villamor, G.B.; Attua, E.M.; Traore, S.B. Comparing farmers' perception of climate change and variability with historical climate data in the Upper East Region of Ghana. Ghana J. Geogr. 2015, 7, 47-74.

52. Esayas, B.; Simane, B.; Teferi, E.; Ongoma, V.; Tefera, N. Climate Variability and Farmers' Perception in Southern Ethiopia. Adv. Meteorol. 2019, 1, 19. [CrossRef]

53. Agwu, O.P.; Bakayoko, A.; Jimoh, S.O.; Stefan, P. Farmers' perceptions on cultivation and the impacts of climate change on goods and services provided by Garcinia kola in Nigeria. Ecol. Process. 2018, 7, 36. [CrossRef]

54. Gbetibouo, G.A. Understanding farmers' perceptions and adaptations to climate change and variability: The case of the Limpopo basin, South Africa. IFPRI 2009, 52. [CrossRef]

55. Tume, S.J.; Kimengsi, J.N.; Fogwe, Z.N. Indigenous knowledge and farmer perceptions of climate and ecological changes in the bamenda highlands of cameroon: Insights from the bui plateau. Climate 2019, 7, 138. [CrossRef]

56. Singh, S. Farmers' perception of climate change and adaptation decisions: A micro-level evidence from Bundelkhand Region, India. Ecol. Indic. 2020, 116, 106475. [CrossRef]

57. Debela, N.; Caroline, M.; Bridle, K.; Corkrey, R.; McNeil, D. Perception of climate change and its impact by smallholders in pastoral/agropastoral systems of Borana, South Ethiopia. Springerplus 2015, 4, 236. [CrossRef] [PubMed]

58. Yamba, S.; Appiah, D.O.; Siaw, L.P.; Casadevall, S.R. Smallholder farmers' perceptions and adaptive response to climate variability and climate change in southern rural Ghana. Cogent Soc. Sci. 2019, 5, 1646626. [CrossRef]

59. Li, R.; Shi, Y.; Shi, L.; Alsaedi, M.; Wang, P. Harvesting Water from Air: Using Anhydrous Salt with Sunlight. Environ. Sci. Technol. 2018, 52, 5398-5406. [CrossRef] [PubMed]

60. Asadieh, B.; Krakauer, N.Y. Impacts of Changes in Precipitation Amount and Distribution on Water Resources Studied Using a Model Rainwater Harvesting System. J. Am. Water Resour. Assoc. 2016, 52, 1450-1471. [CrossRef]

61. Wang, C.; Linderholm, H.W.; Song, Y.; Wang, F.; Liu, Y.; Tian, J.; Xu, J.; Song, Y.; Ren, G. Impacts of Drought on Maize and Soybean Production in Northeast China During the Past Five Decades. Int. J. Environ. Res. Public Health 2020, 17, 2459. [CrossRef]

62. Hatfield, J.L.; Prueger, J.H. Temperature extremes Effect on plant growth and development Weather and Climate Extremes. Weather Clim. Extr. 2015, 10, 4-10. [CrossRef]

63. Omoyo, N.N.; Wakhungu, J.; Oteng'i, S. Effects of climate variability on maize yield in the arid and semi-arid lands of lower eastern Kenya. Agric. Food Secur. 2015, 4, 8. [CrossRef]

64. Chhogyel, N.; Kumar, L.; Bajgai, Y.; Hasan, M.K. Perception of farmers on climate change and its impacts on agriculture across various altitudinal zones of Bhutan Himalayas. Int. J. Environ. Sci. Technol. 2020, 17, 3607-3620. [CrossRef]

65. Harvey, C.A.; Rodríguez, M.S.; Martinez-Rodríguez, M.R.; Viguera, B.; Chain-Guadarrama, A.; Vignola, R. Climate change impacts and adaptation among smallholder farmers in Central America. Agric. Food Secur. 2018, 7, 57. [CrossRef]

66. Hamidov, A.; Helming, K.; Bellocchi, G.; Bojar, W.; Dalgaard, T.; Ghaley, B.B.; Hoffmann, C.; Holman, I.; Holzkämper, A.; Krzeminska, D.; et al. Impacts of climate change adaptation options on soil functions: A review of European case-studies. L. Degrad. Dev. 2018, 29, 2378-2389. [CrossRef]

67. Jackson, R.B.; Le Quéré, C.; Andrew, R.M.; Canadell, J.G.; Korsbakken, J.I.; Liu, Z.; Peters, G.P.; Zheng, B. Global energy growth is outpacing decarbonization. Environ. Res. Lett. 2018, 13, 120401. [CrossRef]

68. Naveenkumar, K.L.; Sen, D.; Khanna, V.K. Effect of Maize Production in a Changing Climate: Its Impacts, Adaptation, and Mitigation Strategies through Breeding. Open Access J. Oncol. Med. 2018, 2, 186-191. [CrossRef]

69. Richard, Y.; Kangalawe, M.; Lyimo, J.G. Climate Change, Adaptive Strategies and Rural Livelihoods in Semiarid Tanzania. Nat. Resour. 2013, 4, 266-278. [CrossRef]

70. Abate, T.; Shiferaw, B.; Menkir, A.; Wegary, D.; Kebede, Y.; Tesfaye, K.; Kassie, M.; Bogale, G.; Tadesse, B.; Keno, T. Factors that transformed maize productivity in Ethiopia. Food Secur. 2015, 7, 965-981. [CrossRef]

71. Jensen, E.S.; Carlsson, G.; Hauggaard-Nielsen, H. Intercropping of grain legumes and cereals improves the use of soil N resources and reduces the requirement for synthetic fertilizer N: A global-scale analysis. Agron. Sustain. Dev. 2020, 40, 5. [CrossRef]

72. Mohammed, U.; Kibret, K.; Mohammed, M.; Diriba, A. Soil Fertility Assessment and Mapping of Becheke Sub-Watershed in Haramaya District of East Hararghe Zone of Oromia Region, Ethiopia. J. Nat. Sci. Res. 2018, 8, 14-36.

73. Chichongue, O.; Pelser, A.; Tol, J.V.; Preez, C.D.; Ceronio, G. Factors influencing the adoption of conservation agriculture practices among smallholder farmers in Mozambique. Int. J. Agric. Ext. 2020, 7, 277-291. [CrossRef]

74. Fung, K.M.; Tai, A.P.K.; Yong, T.; Liu, X.; Lam, H.M. Co-benefits of intercropping as a sustainable farming method for safeguarding both food security and air quality. Environ. Res. Lett. 2019, 14, 044011. [CrossRef]

75. Ndhleve, S.; Nakin, M.D.V.; Longo-Mbenza, B. Impacts of supplemental irrigation as a climate change adaptation strategy for maize production: A case of the Eastern Cape Province of South Africa. Water SA 2017, 43, 222-228. [CrossRef]

76. Shrestha, N. Detecting Multicollinearity in Regression Analysis. Am. J. Appl. Math. Stat. 2020, 8, 39-42. [CrossRef]

77. Erena, N.; Gemechu, A. Analysis on Determinants of Adaptation Options to Climate change of Maize Smallholder Farmers in the South-Eastern part of Ethiopia. J. Nat. Sci. Res. 2016, 6, 32-50. 
78. Tazeze, A.; Haji, J.; Mengistu, K. Climate Change Adaptation Strategies of Smallholder Farmers: The Case of Babilie District, East Harerghe Zone of Oromia Regional State of Ethiopia. J. Econ. Sustain. Dev. 2012, 3, 1-13.

79. Abebe, G.; Debebe, S. Factors Affecting Use of Organic Fertilizer among Smallholder Farmers in Sekela District of Amhara Region, Northwestern Ethiopia. Cogent Food Agric. 2019, 5, 1669398. [CrossRef]

80. Phillipo, F.; Bushesha, M.; Mvena, Z.S.K. Adaptation strategies to climate variability and change and its limitations to smallholder farmers. Asian J. Agric. Rural Dev. 2015, 5, 77-87. [CrossRef]

81. Silvestri, S.; Bryan, E.; Ringler, C.; Herrero, M.; Okoba, B. Climate change perception and adaptation of agro-pastoral communities in Kenya. Reg. Environ. Chang. 2012, 12, 791-802. [CrossRef]

82. Hassan, R.; Nhemachena, C. Determinants of African farmers' strategies for adapting to climate change: Multinomial choice analysis. Environ. Manag. 2008, 114, 83-104. [CrossRef]

83. Sorech, E.M. Trend Analysis and Challenges of Adaptations to Climate Change in Hararghe, Ethiopia. Environ. Pollut. Clim. Chang. 2017, 1, 118. [CrossRef]

84. Vaughan, C.; Hansen, J.; Roudier, P.; Watkiss, P.; Carr, E. Evaluating agricultural weather and climate services in Africa: Evidence, methods, and a learning agenda. WIREs Clim Chang. 2019, 10. [CrossRef] 